\title{
HUBUNGAN IKLAN DAN CITRA MEREK DENGAN KEPUTUSAN PEMBELIAN SHAMPO CLEAR PADA SWALAYAN FADILLAH KOTA BENGKULU
}

\author{
Tito Irwanto, Wahyu Hariyadi \\ Fakultas Ekonomi Universitas Dehasen Bengkulu \\ tito.irwanto22@gmail.com
}

\begin{abstract}
ABSTRAK
Tito Irwanto, Wahyu Hariyadi; Penelitian ini bertujuan untuk mengetahui hubungan iklan dan citra merek dengan keputusan pembelian shampo clear pada Swalayan Fadillah Kota Bengkulu. Sampel dalam penelitian ini sebanyak 50 pelanggan yang membeli sampo jernih. Metode pengumpulan data menggunakan kuesioner. Metode analisis menggunakan korelasi rank spearman dan uji hipotesis dengan uji t. Iklan memiliki korelasi kuat dengan keputusan pembelian sampo yang jelas di Swalayan Fadillah Kota Bengkulu dengan nilai korelasi 0,757, artinya semakin baik iklan yang dibuat oleh perusahaan sampo yang jelas maka semakin tinggi keputusan pembelian sampo jelas di Swadayan Fadillah Kota Bengkulu. . Hasil ini diperkuat oleh hasil uji hipotesis bahwa thitung lebih besar dari ttabel (8,025> 1,677). Dengan demikian hasil hipotesis ditolak H01 dan Ha1 diterima. Ini berarti bahwa iklan tersebut memiliki korelasi yang signifikan dengan keputusan pembelian sampo yang jelas di Swadayan Fadillah Kota Bengkulu. Citra merek dengan keputusan pembelian keputusan sampo jernih di Swadayan Fadillah Kota Bengkulu memiliki korelasi yang sangat kuat dengan nilai korelasi 0,831, ini berarti citra brand Clear Shampoo yang lebih baik maka semakin tinggi keputusan pembelian sampo jelas pada Swadayan Fadillah Bengkulu Kota. Hal ini diperkuat oleh hasil uji hipotesis bahwa thitung lebih besar dari ttabel (10,358> 1,677). Dengan demikian hasil dari hipotesis adalah H02 ditolak dan Ha2 diterima. Ini berarti bahwa citra merek memiliki hubungan yang signifikan dengan keputusan pembelian sampo yang jelas di Swadayan Fadillah Kota Bengkulu
\end{abstract}

ABSTRACT

Tito Irwanto, Wahyu Hariyadi; This study aims to determine the relationship of advertising and brand image with purchase decision of shampo clear on Swalayan Fadillah of Bengkulu City. The sample in this study as many as 50 customers who purchase shampoo clear. The data collection method was used questionaire. The analysis method was used spearman rank correlation and hypothesis test with $t$ test. Advertisement has a strong correlation with purchase decision of shampoo clear on Swalayan Fadillah of Bengkulu City with correlation value of 0.757, means that the better the advertisement made by the company of shampoo clear then the higher of purchase decision of shampoo clear at Swadayan Fadillah Bengkulu City. This result is reinforced by the hypothesis test result that $t_{\text {count }}$ is bigger than table $(8,025>$ 1,677). Thus the result of the hypothesis is $H_{01}$ rejected and $H_{a 1}$ accepted. This means that the advertisement has a significant correlation with purchase decision of shampoo clear on Swadayan Fadillah Bengkulu City. Brand image with the decision to purchase decision of shampoo clear on Swadayan Fadillah Bengkulu City has a very strong correlation with a correlation value of 0.831, this means that the better brand image Clear Shampoo then the higher of purchase decision of shampoo clear on Swadayan Fadillah Bengkulu City. This is reinforced by the result of hypothesis test that $t_{\text {count }}$ is bigger than table $(10,358>1,677)$. Thus the result of the hypothesis is $H_{02}$ rejected and $H_{a 2}$ accepted. This means that the brand image has a significant relationship with purchase decision of shampoo clear on Swadayan Fadillah Bengkulu City

Key Words: Advertisement, Brand Image, Purchase Decision

\section{LATAR BELAKANG}

Perusahaan nasional saat ini tidak hanya bersaing dengan perusahaan lokal tetapi juga dengan perusahaan multinasional. Perubahan dinamis kondisi ekonomi dan sosial telah mengubah secara drastik minat beli konsumen dengan semakin banyaknya pilihan produk, konsumen telah memiliki ekspektasi yang lebih besar dan lebih menantang dari pada sebelumnya. Mereka tidak hanya mengharapkan produk yang berkualitas tinggi karena kualitas produk telah menjadi suatu kewajaran dan persyaratan umum. Jenis baru konsumen ini menginginkan produk yang berkualitas tinggi dengan harga terjangkau oleh mereka.

Perusahaan harus dapat merebut konsumen dari tangan pesaing dengan memberikan value yang lebih besar. Pemasaran modern memerlukan lebih dari sekedar mengembangkan produk yang baik, menawarkannya dengan harga yang menarik, dan membuatnya mudah didapat oleh pelanggan sasaran. Salah satu strategi 
komunikasi yang paling efektif adalah promosi. Promosi merupakan elemen dalam marketing mix yang dipakai perusahaan untuk memasarkan kebutuhannya. Kotler (2013:15) menyatakan bahwa promosi merupakan seluruh aktifitas perusahaan untuk menginformasikan suatu produk termasuk didalamnya usaha untuk mempengaruhi konsumen dengan membujuk, maupun mengingatkan konsumen akan keberadaan produk mereka. Jadi promosi merupakan salah satu aspek yang penting dalam manajemen pemasaran, dan sering dikatakan sebagai "proses berlanjut" ini disebabkan karena promosi dapat menimbulkan rangkaian kegiatan selanjutnya dari perusahaan.

Perusahaan-perusahaan selalu mencari cara-cara untuk mendapatkan efisiensi dengan mengganti satu alat promosi dengan yang lain, bila keadaan ekonomisnya sudah lebih mengguntungkan. Media promosi yang sering digunakan untuk menyampaikan informasi tentang produk adalah media periklanan. Periklanan merupakan salah satu media yang digunakan perusahaan, bisa diklasifikasikan menurut tujuannya yaitu, untuk memberikan informasi, membujuk dan mengingatkan Kotler (2013:34). Inti dari periklanan adalah untuk memasukan sesuatu dalam pikiran konsumen dan mendorong konsumen untuk bertindak atau adanya kegiatan periklanan sering mengakibatkan terjadinya penjualan dengan segera, meskipun banyak juga penjualan terjadi pada waktu mendatang.

Dengan demikian, secara umum dapat dikatakan bahwa tujuan periklanan adalah untuk meningkatkan penjualan yang menguntungkan Iklan bisa digunakan untuk membentuk citra jangka panjang sebuah produk dan juga untuk menggerakkan penjualan cepat. Iklan merupakan cara efisien untuk mencapai banyak pembeli yang secara geografis tersebar. Iklan haruslah dilaksanakan dalam skala cukup besar untuk membuat kesan yang efektif terhadap pasarnya. Masalah dana iklan tergantung pada media yang dipilihnya tentunya iklan melalui televisi membutuhkan anggaran yang besar, dibandingkan iklan surat kabar, radio, brosur, pamflet, baliho dan lain-lain, bisa dilaksanakan dengan anggaran kecil.

Perubahan yang sangat cepat dalam bidang industri mengakibatkan membanjirnya produk-produk yang masuk kepasaran. Setiap konsumen mempunyai sikap dan perilaku yang berbeda-beda terhadap suatu produk. Sukses tidaknya suatu produk dipengaruhi oleh citra merek yang dibangun perusahaan terhadap produk yang bersangkutan. Membangun citra merek adalah tugas penting manajemen pemasaran, agar produk yang di tawarkan perusahaan tertananam di benak konsumen. Dengan mengidentifikasi pasar, maka perusahaan dapat mengetahui strategi apa yang akan dipakai dan digunakan dalam membangun citra merek.

Perkembangan dunia periklanan pada saat ini yang semakin pesat dan didukung oleh pertumbuhan media cetak maupun jumlah stasiun televisi (media elektronik) yang terus meningkat, membuat perusahaan harus selektif dalam membuat iklan untuk mendukung penjualannya. Strategi pemasaran dan promosi yang tepat dan efisien diperlukan untuk membangun citra merek agar produk yang ditawarkan tertanam di benak konsumen.

Untuk melihat hubungan iklan dan citra merek shampoo clear dengan keputusan pembelian, maka penelitian dilakukan di Swalayan Fadillah Kota Bengkulu. Pemilihan objek penelitian pada Swalayan Fadillah Kota Bengkulu dikarenakan tingginya tingkat penjualan shampoo clear di Swalayan Fadillah kota Bengkulu jika dibandingkan dengan shampoo merek lainnya. Swalayan Fadillah Kota Bengkulu merupakan sebuah mini market yang menjual berbagai macam keperluan sehari-hari, termasuk salah satunya adalah shampo clear. Konsumen yang menjadi pelanggan Swalayan Fadillah Kota Bengkulu memerlukan shampoo yang tepat untuk memberikan kenyamanan. Keputusan pembelian konsumen untuk membeli shampoo yang mereka pakai, ketika memiliki kencenderungan menyukai baik dari model endorser maupun fungsi dan manfaat dari shampoo itu sendiri.

Iklan Shampoo Clear merupakan salah satu iklan yang di tampilkan di media masa cetak maupun elektronik.Biasanya dalam iklan Samphoo Clear tersebut menampilkan artis-artis Icon anak muda yang bertujuan untuk menarik para konsumennya khususnya remaja. Seperti iklan shampo yang di yang dibintangi oleh sederatan public figur muda seperti, Irfan Bachdim ,Ello, dan model internasional Cristiano Ronaldo yang merupakan idola anak muda zaman sekarang yang mengunakan motto "Mengatasi rambut tanpa ketombe dan menyehatkan kulit kepala". Di iklan shampoo Clear ini bagaimana diperlihatkan problema rambut yang berketombe yang banyak ditemukan pada kalangan remaja yang aktif dalam beraktifitas sehingga ketombe dapat menghalanggi aktifitas dan mengurangi rasa percaya diri, dari sisi problema itulah Clear menciptakan produk shampoo anti ketombe.

\section{LANDASAN TEORI}

\section{Manajemen Pemasaran}

Pemasaran merupakan bagian yang sangat penting dalam perusahaan. Bagian pemasaran mempunyai tanggung jawab untuk membantu manajemen puncak dalam menyeleksi satu atau lebih kelompok pembeli yang akan dilayani organisasi dan mengkombinasikan kemampuan organisasi untuk mempengaruhi konsumen ke dalam suatu rangkaian kegiatan yang terkoordinir. 
Menurut Swasta dan Irawan (2009: 8), manajemen pemasaran adalah penganalisaan, perencanaan, pelaksanaan dan pengawasan program-program yang ditujukan untuk mengadakan pertukaran dengan pasar yang dituju dengan maksud untuk mencapai tujuan organisasi..

Selanjutnya definisi pemasaran menurut Kotler (2009: 8), "Pemasaran adalah proses sosial dan manajerial baik individu atau kelompok untuk mendapatkan apa yang mereka butuhkan dan diinginkan dengan menciptakan, menawarkan dan mempertukarkan produk yang bernilai dengan pihak lain”.

Sedangkan menurut Stanton (2007: 59), "pemasaran adalah suatu sistem keseluruhan dan kegiatan bisnis yang ditunjukan untuk merencanakan, menentukan harga, mempromosikan dan mendistribusikan barang dan jasa yang memuaskan baik kepada pembeli yang ada maupun pembeli yang potensial".

Dari definisi-definisi di atas dapat diambil beberapa hal penting peran pemasaran, yaitu :

1. Proses manajemen pemasaran terdiri dari penganalisaan, perencanaan, pelaksanaan. dan pengelolaan kemampuan perusahaan untuk mempengaruhi (produk, harga, promosi dan distribusi).

2. Konsep produk sangat luas terdiri dari barang fisik, jasa, ide-ide.

3. Proses pemasaaran terdiri dari kegiatan pertukaran antara pihak-pihak (pembeli dan penjual) yang berusaha untuk memuaskan tujuan keduanya.

4. Konsep pemasaran menggambarkan proses penyebaran tanggung jawab seluruh perusahaan, dan bukan hanya fungsi organisasi yang terspesialisasi.

\section{Konsep Pemasaran}

Pemasaran mempunyai pengertian yang luas, tidak hanya merupakan aktivitas penjualan saja. Pemasaran telah didefinisikan dalam berbagai cara yang berbeda dan oleh penulis yang berbeda. Jadi yang paling penting dalam kegiatan pemasaran yaitu harus berhubungan dengan adanya pemindahan hak milik secara memuaskan.

Menurut Kotler (2009 : 5), konsep pemasaran meliputi :
a. Kebutuhan, keinginan dan permintaan
b. Produk
c. Nilai, biaya dan kepuasan
d. Pertukaran, transaksi dan hubungan
e. Pasar
f. Pemasaran dan pemasar

Gambar 1. Konsep Pemasaran:

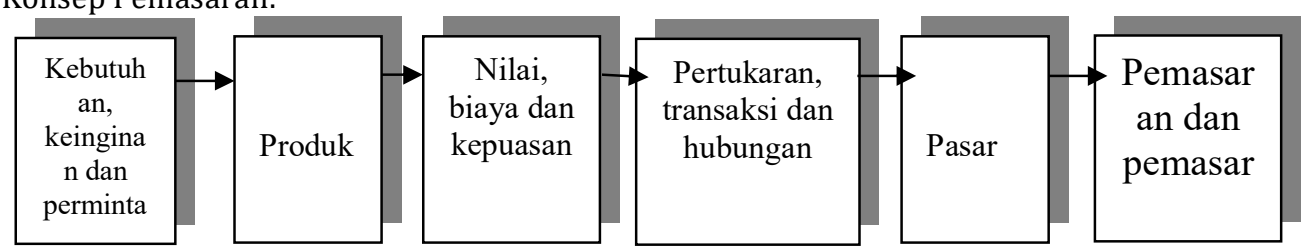

Sumber : Kotler, (2009: 5)

Berdasarkan Gambar 1 diatas dapat dijabarkan, sebagai berikut :

a. Kebutuhan, keinginan dan permintaan

Ada perbedaan antara kebutuhan, keinginan dan permintaan. Kebutuhan manusia adalah keadaan merasa tidak memiliki kepuasan dasar. Kebutuhan ini tidak diciptakan oleh masyarakat atau pemasar, namun sudah ada terukir dalam hayati serta kondisi manusia.

Keinginan adalah hasrat akan pemuas tertentu dari kebutuhan tersebut. Sedangkan permintaan adalah keinginan akan suatu produk yang didukung dengan kemampuan serta kesediaan membelinya. Keinginan menjadi permintaan bila didukung dengan daya beli.

b. Produk

Orang memenuhi kebutuhan dan keinginannya dengan barang dan jasa. Produk didefinisikan sebagai sesuatu yang dapat ditawarkan untuk memenuhi kebutuhan dan keinginan. Pentingnya suatu produk fisik bukan terletak pada kepemilikannya, tetapi pada jasa yang dapat diberikan. Sebagai contoh kita tidak dapat membeli mobil untuk dilihat saja, melainkan untuk jasa trasportasinya.

c. Nilai, biaya dan kepuasan 
Konsep dasarnya adalah nilai konsumen, konsumen akan membentuk suatu prakiran kemampuan setiap produk yang dapat memenuhi kelompok kebutuhannya. Ia akan menentukan peringkat produk, dari yang paling memenuhi sampai yang tidak memenuhi kebutuhannya. Nilai adalah perkiraan konsumen tentang kemampuan total suatu produk untuk memenuhi kebutuhannya. Jadi ia akan mempertimbangkan nilai dan harga suatu produk sebelum menentukan pilihan. Ia akan memilih produk memberikan nilai tertinggi untuk harganya.

d. Pertukaran, transaksi dan hubungan

Pemasaran timbul saat orang memutuskan untuk memenuhi kebutuhan serta keinginannya dengan pertukaran. Pertukaran merupakan salah satu dari empat cara orang mendapatkan suatu produk.

Pertukaran adalah cara mendapatkan suatu produk yang diinginkan dari seseorang dengan cara menawarkan sesuatu sebagai gantinya. Pertukaran ini adalah konsep dasar permintaan. Supaya terjadi pertukaran, ada lima syarat yang harus dipenuhi (Staton, 2007:101):

1. Ada sekurang-kurangnya dua pihak.

2. Masing-masing pihak memiliki sesuatu yang bernilai bagi pihak lainnya.

3. Masing-masing pihak dapat berkomunikasi dan menyerahkan barang.

4. Masing-masing pihak bebas menerima atau menerima penawaran yang ada.

5. Masing-masing pihak memang menginginkan dan bersedia berurusan dengan pihak lainnya.

Kalau lima syarat tersebut dipenuhi, ada kemungkinan terjadi pertukaran. Terjadi atau tidaknya pertukaran tergantung apakan kedua belah pihak dapat menyetujui syarat pertukaran yang saling menguntungkan (atau minimal tidak merugikan). Jadi pertukaran sering disebut "proses penciptaan nilai", karena masing-masing pihak biasanya lebih beruntung dari pada sebelum pertukaran.

Untuk menghasikan suatu pertukaran, pemasar menganalisis apa yang masing-masing pihak harapkan untuk diperoleh dan diberikan. Pemasar yang baik akan mencoba membangun suatu hubungan jangka panjang, saling percaya "sama-sama menang" dengan para konsumen, distributor, penyalur dan pemasoknya yang ia hargai. Hal ini dicapai dengan harga yang wajar kepada mitranya secara berkesinambungan.

e. Pasar

Pasar terdiri dari semua konsumen potensial yang memiliki kebutuhan atau keinginan tertentu serta mau dan mampu turut dalam pertukaran untuk memenuhi kebutuhan atau keinginan itu. Jadi besarnya pasar tergantung dari jumlah orang memiliki kebutuhannya, punya sumber daya yang diminati orang lain, dan mau menawarkan sumber daya itu untuk ditukar, supaya dapat memenuhi kebutuhan mereka.

Semua istilah pasar menunjukan tempat dimana penjual dan pembeli berkumpul untuk menukar barang-barang mereka. Ahli ekonomi menggunakan istilah pasar untuk menunjukan pada sejumlah pembeli dan penjual yang melakukan transaksi pada suatu produk atau kelas produk.

f. Pemasaran dan pemasar

Konsep pasar membawa kita kembali pada konsep pemasaran. Pemasaran adalah kegiatan manusia dalam hubungannya dengan pasar. Pemasaran maksudnya bekerja dengan pasar untuk mewujudkan transaksi yang mungkin terjadi dalam memenuhi keinginan dan kebutuhan manusia. Kalau satu pihak lebih aktif mencari pertukaran dari pihak lain, maka pihak pertama adalah pemasar dan pihak kedua adalah calon pembeli. Pemasar adalah orang yang mencari sumber daya dari orang lain dan mau menawarkan sesuatu yang bernilai, untuk itu keefektifan mereka dipengaruhi oleh masing-masing pemasok mereka dan juga faktor utama lingkungan (demografi, ekonomi, fiscal, teknologi, politik, hukum, sosial dan budaya).

Iklan

Untuk memperkenalkan suatu produk terhadap konsumen maka diperlukan suatu strategi pemasaran yaitu iklan, karena dengan adanya iklan maka suatu produk dapat lebih dikenal oleh konsumen. Iklan yang ditayangkan dimedia cetak maupun media elektronik akan menarik perhatian konsumen dan menimbulkan minat dari konsumen untuk mengetahui produk yang di iklankan.

Menurut Peter dan Olson (2010:181) iklan adalah penyajian informasi nonpersonal tentang suatu produk, merk, perusahaan atau toko yang dilakukan dengan bayaran tertentu. Pada iklan biasanya ditampakkan organisasi yang mensponsorinya. Iklan ditujukan untuk mempengaruhi afeksi, dan kognisi konsumen-evaluasi, perasaan, pengetahuan, makna, kepercayaan, sikap dan citra yang berkaitan dengan citra dan merk. Dalam prakteknya iklan dianggap sebagai manajemen citra (image Management) menciptakan dan memelihara citra dan makna dalam benak konsumen. Walaupun pertama-tama iklan 
akan mempengaruhi afeksi dan kognisi, tujuannya yang paling akhir adalah bagaimana mempengaruhi perilaku pembelian konsumen.

Selanjutunya defenisi iklan juga disampaikan oleh Tjiptono (2007:226) bahwa iklan adalah bentuk komunikasi tidak langsung, yang didasar pada informasi tentang keunggulan atau keuntungan suatu produk, yang disusun sedemikian rupa sehingga menimbulkan rasa yang menyenangkan yang akan mengubah pikiran seseorang untuk melakukan pembelian.

Pengenalan produk kepada konsumen dapat dilakukan dengan cara mempresentasikannya melalui sebuah media yang dibayar, hal ini sesuai dengan pendapat yang disampaikan oleh Kotler (2013:277) menyatakan bahwa iklan adalah segala bentuk presentasi non-pribadi dan promosi gagasan, barang, atau jasa oleh sponsor tertentu yang harus dibayar".

Menurut Saladin (2013:133), terdapat 4 ciri-ciri khas periklanan (Advertising), yaitu:

1. Penyajian Dimuka Umum (Public Presentation)

Iklan merupakan suatu sarana komunikasi yang sangat bersifat umum.

2. Pencerahan Menyeluruh (Pervasiveness)

Iklan merupakan medium yang diserap secara menyeluruh dan memungkinkan pihak perusahaan untuk menanggulangi pesaingnya.

3. Daya Ungkap Yang Kuat (Expresivenes)

Iklan memberikan peluang untuk menampilkan perusahaan serta produknya dengan cara yang mengesankan dengan penggunaan secukupnya, bunyi dan warna secara cerdas.

4. Kurang Kepribadian (Impresonality) Iklan senantiasa bersifat umum, daya meyakinkan dan mengungkapkan masih kurang.

Menurut Kotler (2013:143) indikator iklan adalah sebagai berikut:

1. Mission (tujuan) yaitu menetapkan tujuan periklanan yang merujuk pada keputusan sebelumnya mengenai pasar sasaran, penentuan pasar sasaran, penentuan posisi pasar, dan bauran promosi. Strategi penentuan posisi pemasaran dan strategi bauran pemasaran mengidentifikasikan tugas yang harus dilaksanakan periklanan dalam pelaksanaan program pemasaran keseluruhan.

2. Message (pesan yang disampaikan), idealnya suatu pesan harus mendapat perhatian, menarik, membangkitkan keinginan, dan menghasilkan tindakan.

3. Media (media yang digunakan), pada dasarnya pemilihan media adalah mencari cara dengan biaya yang paling efektif untuk menyampaikan sejumlah pemberitahuan yang dikehendaki kepada pasar sasaran. Pengaruh pemberitahuan iklan terhadap kesadaran khalayak sasaran tergantung kepada jangkauan, frekuensi dan dampak iklan.

\section{Citra Merek}

Menurut Kotler (2013:142) menyebutkan citra merek adalah persepsi masyarakat terhadap perusahaan atau produknya. Citra dipengaruhi oleh banyak faktor yang di luar kontrol perusahaan. Citra yang efektif akan berpengaruh terhadap tiga hal yaitu : pertama, memantapkan karakter produk dan usulan nilai. Kedua, menyampaikan karakter itu dengan cara yang berbeda sehingga tidak dikacaukan dengan karakter pesaing. Ketiga, memberikan kekuatan emosional yang lebih dari sekadar citra mental. Supaya bisa berfungsi citra harus disampaikan melalui setiap sarana komunikasi yang tersedia dan kontak merek.

Menurut Hossain (2007:76) menyatakan bahwa citra merek adalah keseluruhan dari persepsi konsumen mengenai merek atau bagaimana mereka mengetahuinya. Hal tersebut dipertegas oleh Simamora (2008:56) bahwa citra adalah persepsi yang relatif konsisten dalam jangka panjang (enduring perception) maka tidak mudah untuk membentuk citra, sehingga bila telah terbentuk akan sulit mengubahnya.

Menurut Supranto dan Limakrisma (2011:98) menyatakan citra merek adalah apa yang konsumen pikir dan rasakan ketika mendengar atau melihat suatu merek dan apa yang konsumen pelajari tentang merek. Sehingga dapat disimpulkan bahwa citra merek adalah sekumpulan asosiasi merek yang dapat konsumen rasakan dan dipikirkan yang diciptakan dan dipelihara oleh pemasar agar terbentuk di dalam benak konsumen.

Menurut Kotler dan Keller (2009:103) citra merek adalah sejumlah keyakinan, ide, dan kesan yang dipegang oleh seseorang tentang sebuah objek. Sedangkan citra merek adalah persepsi dan keyakinan yang dipegang oleh konsumen, seperti yang dicerminkan asosiasi yang tertanam dalam ingatan konsumen. Sedangkan menurut Utami (2010:67) citra merek adalah serangkaian asosiasi yang biasanya diorganisasikan di seputar beberapa tema yang bermakna.

Menurut Roslina (2010:77) mendefinisikan bahwa "Citra merek merupakan petunjuk yang akan digunakan oleh konsumen untuk mengevaluasi produk ketika konsumen tidak memiliki pengetahuan 
yang cukup tentang suatu produk". Terdapat kecenderungan bahwa konsumen akan memilih produk yang telah dikenal baik melalui pengalaman menggunakan produk maupun berdasarkan informasi yang diperoleh melalui berbagai sumber.

Menurut Tjiptono (2011:37) bahwa brand image atau citra merek adalah merupakan serangkaian asosiasi yang dipersepsikan oleh individu sepanjang waktu, sebagai hasil pengalaman langsung maupun tidak langsung atas sebuah merek.

Berdasarkan beberapa pengertian diatas maka citra merek menurut penulis adalah persepsi konsumen untuk mengevaluasi suatu produk ketika konsumen tidak memiliki pengetahuan yang cukup baik tentang suatu produk. Konsumen cenderung akan memilih produk yang telah terkenal dan digunakan oleh banyak orang daripada produk yang baru dikenalnya.

Menurut Sciffman dan Kanuk (2010:136) ada beberapa indikator pembentuk citra merek, sebagai berikut :

1. Kualitas dan mutu, berkaitan dengan kualitas produk barang yang ditawarkan oleh produsen dengan merek tertentu.

2. Dapat dipercaya atau diandalkan, berkaitan dengan pendapat atau kesepakatan yang dibentuk oleh masyarakat tentang suatu produk yang dikonsumsi.

3. Kegunaan atau manfaat, yang terkait dengan fungsi dari suatu produk yang bisa dimanfaatkan oleh konsumen.

4. Resiko, terkait dengan besar kecilnya akibat untung dan rugi yang mungkin dialami oleh konsumen.

5. Harga, yang dalam hal ini berkaitan dengan tinggi rendahnya atau banyak sedikitnya jumlah uang yang dikeluarkan oleh konsumen untuk mempengaruhi suatu produk, juga dapat mempengaruhi citra jangka panjang.

6. Citra yang dimiliki oleh merek itu sendiri, yaitu berupa pandangan, kesepakatan, dan informasi yang berkaitan dengan suatu merek dari produk tertentu.

\section{Keputusan Pembelian}

Menurut Machfoedz (2010:44) mengemukakan bahwa pengambilan keputusan adalah suatu proses penilaian dan pemilihan dari berbagai alternatif sesuai dengan kepentingan-kepentingan tertentu dengan menetapkan suatu pilihan yang dianggap paling menguntungkan. Proses penilaian itu biasanya diawali dengan mengindentifikasi masalah utama yang mempengaruhi tujuan, menyusun, menganalisis, dan memilih berbagai alternatif tersebut dan mengambil keputusan yang dianggap paling baik. Langkah terakhir dari proses itu merupakan sistim evaluasi untuk menentukan efektifitas dari keputusan yang telah diambil.

Menurut Swasta dan Handoko (2008:110) mengemukakan bahwa "Keputusan pembelian merupakan proses dalam pembelian yang nyata, apakah membeli atau tidak".

Adapun faktor-faktor yang memengaruhi konsumen dalam membuat keputusan pembelian menurut Sutisna (2009:6) menggambarkan bahwa konsumen dipengaruhi oleh tiga faktor utama. Ketiga faktor tersebut adalah:

1. Konsumen individual. Artinya pilihan untuk membeli suatu produk dengan merk tertentu dipengaruhi oleh hal-hal yang ada pada diri konsumen. Kebutuhan, persepsi terhadap karakteristik merk, sikap, kondisi demografis, gaya hidup dan karakteristik kepribadian individu akan mempengaruhi pilihan individu itu terhadap berbagai alternatif yang tersedia.

2. Lingkungan yang mempengaruhi konsumen. Pilihan-pilihan konsumen terhadap merk dipengaruhi oleh lingkungan yang mengitarinya. Jadi interaksi sosial yang dilakukan oleh seseorang akan turut mempengaruhi pada pilihan-pilihan merk yang dibeli.

3. Strategi pemasaran. Stretegi pemasaran yang banyak dibahas adalah salah satunya variabel dalam model ini yang dikendalikan oleh pemasar. Dalam hal ini, pemasar berusaha mempengaruhi konsumen dengan menggunakan stimuli-stimuli pemasaran seperti iklan dan sejenisnya agar konsumen bersedia memilih merk produk yang ditawarkan.

Menurut Kotler dan Keller, (2009:184), ada lima tahap yang dilalui konsumen dalam proses pengambilan keputusan, yaitu pengenalan masalah, pencarian informasi, evaluasi alternatif, keputusan pembelian, dan perilaku sesudah pembelian. Model ini menekankan bahwa proses pembelian bermula sebelum pembelian dan berakibat jauh setelah pembelian 
Gambar 2. Proses Keputusan Pembelian

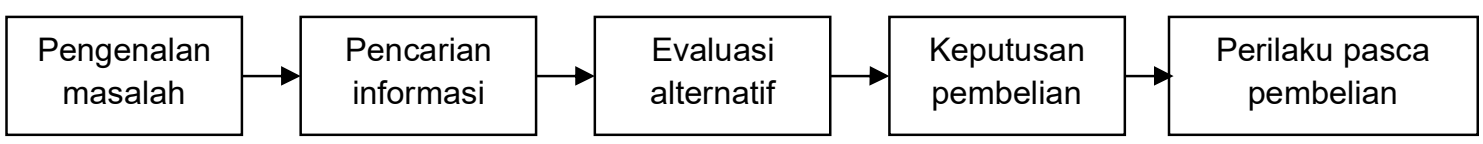

Sumber : Kotler dan Keller, (2009:186)

1. Pengenalan Masalah

Proses dimulai saat pembeli menyadari adanya masalah atau kebutuhan. Pembeli merasakan adanya perbedaan antara yang nyata dan yang diinginkan. Kebutuhan ini disebabkan karena adanya rangsangan internal maupun eksternal.

2. Pencarian Informasi

Seorang konsumen yang terdorong kebutuhannya mungkin, atau mungkin juga tidak, mencari informasi lebih lanjut. Jika dorongan konsumen kuat dan produk itu berada di dekatnya, mungkin konsumen akan langsung membelinya. Jika tidak, kebutuhan konsumen ini hanya akan menjadi ingatan saja.

3. Evaluasi Alternatif

Konsumen memproses informasi tentang pilihan merk untuk membuat keputusan terakhir. Pertama, kita melihat bahwa konsumen mempunyai kebutuhan. Konsumen akan mencari manfaat tertentu dan selanjutnya melihat kepada atribut produk. Konsumen akan memberikan bobot yang berbeda untuk setiap atribut produk sesuai dengan kepentingannya.

4. Keputusan Pembelian

Pada tahap evaluasi, konsumen menyusun merk-merk dalam himpunan pilihan serta membentuk niat pembelian. Biasanya ia akan memilih merk yang disukai. Tetapi ada pula faktor yang mempengaruhi seperti sikap orang lain dan faktor-faktor keadaan yang tidak terduga.

5. Perilaku Pasca Pembelian

Sesudah pembelian terhadap suatu produk, konsumen akan mengalami beberapa tingkat kepuasan atau ketidakpuasan.

a. Kepuasan sesudah pembelian

Konsumen mendasarkan harapannya kepada informasi yang merka terima tentang produk. Jika kenyataan yang merka dapat ternyata berbeda dengan yang diharapkan maka merka merasa tidak puas. Bila produk tersebut memenuhi harapan, merka akan merasa puas.

b. Tindakan sesudah pembelian

Penjualan perusahaan berasal dari dua kelompok, yaitu pelanggan baru dan pelanggan ulang. Mempertahankan pelanggan yang lama adalah lebih penting daripada menarik pelanggan baru. Oleh karena itu, perusahaan harus memperhatikan kepuasan pelanggan. Jika konsumen merasa puas ia akan memperlihatkan kemungkinan untuk membeli lagi produk tersebut.

\section{Kerangka Analisis}

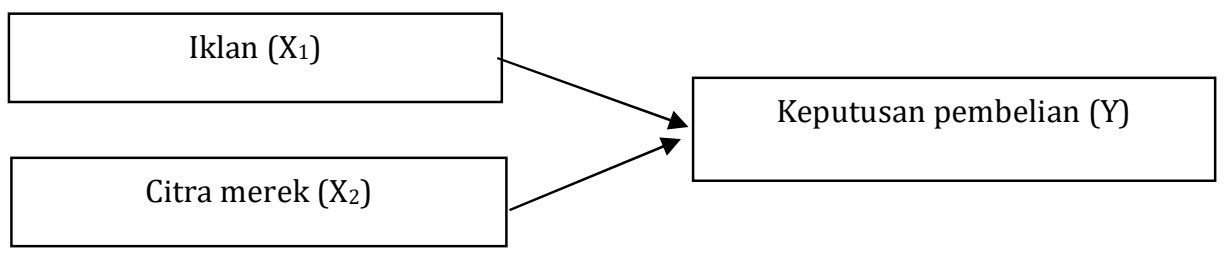

Gambar 1. Kerangka Analisis

\section{Metode Penelitian}

Penelitian ini termasuk jenis penelitian kuantitatif, dimana data penelitian memuat angka-angka dan dianalisis menggunakan statistik (Sugiyono, 2013:13). Sehubungan penelitian ini hanya bersifat menggambarkan suatu hubungan iklan dan citra merek shampo clear dengan keputusan pembelian pada Swalayan Fadillah Kota Bengkulu.

Alat analisi dalam penelitian ini menggunakan korelasi rank spearman dimanasumber data untuk kedua variabel yang akan dikonversikan dapat berasal dari sumber yang tidak sama, jenis data yang dikorelasikan adalah data ordinal, serta data dari kedua variabel tidak harus membentuk distribusi 
normal. Jadi korelasi rank spearman bekerja dengan data ordinal atau berjenjang atau rangking, dan bebas distribusi ( Sugiyono, 2013:245). Rumus korelasi rank spearman dalah :

$$
\rho=1-\frac{6 \sum b i^{2}}{n\left(n^{2}-1\right)}
$$

(Sugiyono, 2013:183)

Keterangan :

$$
\begin{array}{ll}
\rho & =\text { Koefisien Korelasi Spearman Rank } \\
\mathrm{n} & =\text { Jumlah sampel } \\
\sum b i^{2} & =\text { Jumlah kuadrat dari selisih rank variabel } \mathrm{x} \text { dan variabel } \mathrm{y}
\end{array}
$$

Untuk menginterprestasikan angka yang dihasilkan dari perhitungan maka dapat digunakan pedoman sebagai berikut :

Tabel 2. Interprestasi Koefisien Korelasi

\begin{tabular}{|l|l|}
\hline Interval Koefesien & Tingkat Hubungan \\
\hline $0,00-0,199$ & Sangat rendah \\
\hline $0,20-0,399$ & Rendah \\
\hline $0,40-0,599$ & Sedang \\
\hline $0,60-0,799$ & Kuat \\
\hline $0,80-1,000$ & Sangat kuat \\
\hline
\end{tabular}

Sumber : Sugiyono, 2013:184

Uji Hipotesis untuk mengetahui tingkat signifikansi dari korelasi, maka penulis menggunakan statistik uji t dengan rumus sebagai berikut:

$$
\begin{aligned}
& t_{\text {hitung }}=r \sqrt{\frac{n-2}{1-m^{2}}} \\
& \text { ( Sugiyono, } 2013: 251 \text { ) } \\
& \text { Keterangan : } \\
& \mathrm{t}=\text { nilai uji } \mathrm{t} \\
& \mathrm{r}=\text { nilai koefisien korelasi } \\
& \mathrm{n}=\text { jumlah sampel }
\end{aligned}
$$

Agar hasil perhitungan koefisien korelasi dapat diketahui signifikan atau tidak signifikan maka hasil perhitungan dari statistik uji $\mathrm{t}(\mathrm{t}$ hitung) tersebut selanjutnya dibandingkan dengan tabel. Tingkat signifikannya yaitu $5 \%(\alpha=0,05)$ dengan uji satu pihak dan derajat kebebasannya $(\mathrm{dk}=\mathrm{n}-3)$, artinya jika hipotesis nol ditolak dengan taraf kepercayaan 95 \%, maka kemungkinan bahwa hasil dari penarikan kesimpulan mempunyai kebenaran 95 \% dan hal ini menunjukan adanya hubungan (korelasi) yang meyakinkan (signifikan) antara dua variabel tersebut.

\section{Hasil Penelitian Dan Pembahasan Analisis Rank Spearman Hubungan Iklan dengan Keputusan Pembelian Shampoo Clear pada Swalayan Fadillah Kota Bengkulu}

Berdasarkan lampiran 8 tabel penolong perhitungan korelasi rank spearman untuk hubungan iklan dengan keputusan pembelian shampoo clear pada Swalayan Fadillah Kota Bengkulu diketahui datadata sebagai berikut :

$$
\begin{aligned}
\mathrm{n} & =50 \\
\sum \mathrm{bi}^{2} & =5.060
\end{aligned}
$$

$$
\begin{aligned}
& \rho=1-\frac{6(5.060)}{50\left(50^{2}-1\right)} \\
& \rho=1-\frac{30.360}{50(2.500-1)} \\
& \rho=1-\frac{30.360)}{50(2.499)}
\end{aligned}
$$




$$
\begin{aligned}
& \rho=1-\frac{30.360}{124.950} \\
& \rho=1-0,2.43 \\
& \rho=0,757
\end{aligned}
$$

Artinya besarnya nilai hubungan antara iklan dengan keputusan pembelian shampoo clear pada Swalayan Fadillah Kota Bengkulu adalah sebesar 0,757, yang berarti juga memiliki korelasi yang kuat karena angka 0,757 terletak diantara angka 0,50-0,799. Dengan demikian semakin menarik iklan yang diterbitkan oleh perusahaan clear maka akan semakin tinggi pula keputusan pembelian shampoo clear pada Swalayan Fadillah Kota Bengkulu .

\section{Hubungan Citra Merek dengan Keputusan Pembelian Shampoo Clear Pada Swalayan Fadillah Kota Bengkulu}

Berdasarkan lampiran 9 tabel penolong perhitungan korelasi rank spearman untuk hubungan citra merek dengan keputusan pembelian shampoo clear pada Swalayan Fadillah Kota Bengkulu diketahui data-data sebagai berikut :

$$
\begin{aligned}
\mathrm{n} & =50 \\
\sum \mathrm{bi}^{2} & =3.514
\end{aligned}
$$

Selanjutnya dari data tersebut dimasukan kedalam rumus sebagai berikut :

$$
\begin{aligned}
& \rho=1-\frac{6 \sum b i^{2}}{n\left(n^{2}-1\right)} \\
& \rho=1-\frac{6(3.514)}{50\left(50^{2}-1\right)} \\
& \rho=1-\frac{21.084}{50(2.500-1)} \\
& \rho=1-\frac{21.084}{50(2.499)} \\
& \rho=1-\frac{21.084}{124.950} \\
& \rho=1-0,169 \\
& \rho=0,831
\end{aligned}
$$

Artinya besarnya nilai hubungan antara citra merek dengan keputusan pembelian shampoo clear pada Swalayan Fadillah Kota Bengkulu adalah sebesar 0,831 yang berarti juga memiliki korelasi yang sangat kuat karena angka 0,831 terletak diantara angka 0,80-1,000. Ini berarti bahwa semakin bagus citra merek shampoo clear maka akan semakin tinggi pula keputusan pembelian shampoo clear pada Swalayan Fadillah Kota Bengkulu .

\section{Uji Hipotesis}

Uji Hipotesis Hubungan Iklan dengan Keputusan Pembelian Shampoo Clear pada Swalayan Fadillah Kota Bengkulu

Dari hasil perhitungan korelasi rank spearman untuk hubungan iklan dengan keputusan pembelian shampoo clear pada Swalayan Fadillah Kota Bengkulu diperoleh nilai $\rho=0,757$ dengan $n=$ 50, maka dapat diketahui nilai t-hitung sebagai berikut :

$$
\begin{aligned}
& t=t \sqrt{\frac{n-2}{1-r^{2}}} \\
& t=0,757 \sqrt{\frac{50-2}{10,757^{2}}}
\end{aligned}
$$




$$
\begin{aligned}
t & =0,757 \sqrt{\frac{48}{1-0,5737}} \\
t & =0,757 \sqrt{\frac{48}{0.427}} \\
t & =0,757 \sqrt{112,412} \\
t & =0,757(10.602) \\
t & =8,025
\end{aligned}
$$

Nilai thitung sebesar 8,025 kemudian dibandingkan dengan nilai tabel dengan level of signifikan ditetapkan 95\% dengan perhitungan satu arah dan $\mathrm{dk}=\mathrm{n}-2=50-2=48$, yaitu diketahui nilai tabel sebesar 1,677 dengan demijian diketahui bahwa thitung lebih besar dari ttabel $(8,025>1,677)$. Artinya adalah $\mathrm{H}_{01}$ ditolak dan $\mathrm{H}_{\mathrm{a} 1}$ diterima/iklan mempunyai hubungan yang signifikan dengan keputusan pembelian shampoo clear pada Swalayan Fadillah Kota Bengkulu .

\section{Uji Hipotesis Hubungan Citra merek Dengan Keputusan Pembelian Shampoo Clear pada Swalayan Fadillah Kota Bengkulu}

Dari hasil perhitungan korelasi rank spearman untuk hubungan iklan dengan keputusan pembelian shampoo clear pada Swalayan Fadillah Kota Bengkulu diperoleh nilai $\rho=0,831$ dengan $\mathrm{n}=$ 50, maka dapat diketahui nilai t-hitung sebagai berikut :

$$
\begin{aligned}
& t=t \sqrt{\frac{n-2}{1-r^{2}}} \\
& t=0,831 \sqrt{\frac{50-2}{1-0,831^{2}}} \\
& t=0,831 \sqrt{\frac{48}{1-0,691}} \\
& t=0,831 \sqrt{\frac{48}{0,309}} \\
& t=0,831 \sqrt{155,339} \\
& t-0,831(12,464) \\
& t=10,358
\end{aligned}
$$

Nilai thitung sebesar 10,358 kemudian dibandingkan dengan nilai tabel dengan level of signifikan ditetapkan 95\% dengan perhitungan satu arah dan $\mathrm{dk}=\mathrm{n}-2=50-2=48$, yaitu diketahui nilai tabel sebesar 1,677 dengan demikian diketahui bahwa thitung lebih besar dari tabel $(10,358>1,677)$. Artinya adalah $\mathrm{H}_{02}$ ditolak dan $\mathrm{H}_{\mathrm{a} 2}$ diterima/citra merek mempunyai hubungan yang signifikan dengan keputusan pembelian shampoo clear pada Swalayan Fadillah Kota Bengkulu.

Berdasarkan hasil penelitian dapat diketahui bahwa iklan memiliki hubungan yang kuat dengan keputusan pembelian shampoo clear pada Swalayan Fadillah Kota Bengkulu dengan nilai korelasi sebesar 0,757, berarti bahwa semakin bagus iklan yang dilakukan oleh perusahaan clear maka akan semakin tinggi pula keputusan pembelian shampoo clear pada Swalayan Fadillah Kota Bengkulu. Hasil ini diperkuat dengan hasil uji hipotesis bahwa thitung lebih besar dari tabel $(8,025>1,677)$. Dengan demikian hasil hipotesis adalah $\mathrm{H}_{01}$ ditolak dan $\mathrm{H}_{\mathrm{a} 1}$ diterima. Artinya iklan mempunyai hubungan yang signifikan dengan keputusan pembelian shampoo clear pada Swalayan Fadillah Kota Bengkulu .

Hasil penelitian ini sejalan dengan pendapat yang disampaikan oleh Tjiptono (2011:226) bahwa iklan adalah bentuk komunikasi tidak langsung, yang didasar pada informasi tentang keunggulan atau 
keuntungan suatu produk, yang disusun sedemikian rupa sehingga menimbulkan rasa yang menyenangkan yang akan mengubah pikiran seseorang untuk melakukan pembelian.

Dengan adanya iklan mengenai shampo clear yang ditayangkan oleh perusahaan clear baik dimedia elektronik maupun dimedia sosial maka konsumen akan lebih cepat mengetahui tentang produk baru yang ada. Iklan yang dilakukan oleh perusahaan clear mampu menarik perhatian konsumen untuk menggunakan shampoo clear. Apalagi pemilihan bintang iklan yang digunakan sangat dikenal oleh konsumen dan memiliki rambut yang indah, hal ini akan mempengaruhi konsumen untuk membeli shampoo clear.

Hasil penelitian korelasi rank spearman untuk hubungan citra merek dengan keputusan pembelian shampoo clear pada Swalayan Fadillah Kota Bengkulu memiliki korelasi yang sangat kuat dengan nilai korelasi sebesar 0,831, ini berarti bahwa semakin bagus citra merek Swalayan Fadillah Kota Bengkulu maka akan semakin tinggi pula keputusan pembelian shampoo clear pada Swalayan Fadillah Kota Bengkulu . Hal ini diperkuat dengan hasil uji hipotesis bahwa thitung lebih besar dari tabel $(10,358$ $>1,677)$. Dengan demikian hasil hipotesis adalah $\mathrm{H}_{02}$ ditolak dan $\mathrm{H}_{\mathrm{a} 2}$ diterima. Artinya citra merek mempunyai hubungan yang signifikan dengan keputusan pembelian shampoo clear pada Swalayan Fadillah Kota Bengkulu .

Hasil penelitian ini sejalan dengan pendapat Hossain (2007:76) menyatakan bahwa citra merek adalah keseluruhan dari persepsi konsumen mengenai merek atau bagaimana mereka mengetahuinya. Sehingga dapat disimpulkan bahwa citra merek adalah sekumpulan asosiasi merek yang dapat konsumen rasakan dan dipikirkan yang diciptakan dan dipelihara oleh pemasar agar terbentuk di dalam benak konsumen

Berdasarkan hasil penelitian bahwa citra merek memiliki hubungan keputusan pembelian shampoo clear pada Swalayan Fadillah kota Bengkulu. Citra merek yang dimiliki oleh shampoo clear telah melekat di pikiran konsumen sehingga pada saat konsumen ingin membeli shampoo konsumen langsung memutuskan untuk membeli shampoo clear. Karena shampoo clear memiliki berbagai macam keuanggulan seperti dapat menghilangkan ketombe, membuat rambut menjadi indah, rambut akan semakin kuat dan juga akan menyehatkan kulit kepala.

\section{KESIMPULAN}

1. Iklan memiliki hubungan yang kuat dengan keputusan pembelian shampoo clear pada Swalayan Fadillah Kota Bengkulu dengan nilai korelasi sebesar 0,757, berarti bahwa semakin bagus iklan yang dilakukan oleh perusahaan clear maka akan semakin tinggi pula keputusan pembelian shampoo clear pada Swalayan Fadillah Kota Bengkulu . Hasil ini diperkuat dengan hasil uji hipotesis bahwa thitung lebih besar dari tabel (8,025>1,677). Dengan demikian hasil hipotesis adalah $\mathrm{H}_{01}$ ditolak dan $\mathrm{H}_{\mathrm{a}}$ diterima. Artinya iklan mempunyai hubungan yang signifikan dengan keputusan pembelian shampoo clear pada Swalayan Fadillah Kota Bengkulu.

2. Citra merek dengan keputusan pembelian shampoo clear pada Swalayan Fadillah Kota Bengkulu memiliki korelasi yang sangat kuat dengan nilai korelasi sebesar 0,831, ini berarti bahwa semakin bagus citra merek Swalayan Swalayan Fadillah Kota Bengkulu maka akan semakin tinggi pula keputusan pembelian shampoo clear pada Swalayan Fadillah Kota Bengkulu . Hal ini diperkuat dengan hasil uji hipotesis bahwa thitung lebih besar dari tabel $(10,358>1,677)$. Dengan demikian hasil hipotesis adalah $\mathrm{H}_{02}$ ditolak dan $\mathrm{H}_{\mathrm{a}}$ diterima. Artinya citra merek mempunyai hubungan yang signifikan dengan keputusan pembelian shampoo clear pada Swalayan Fadillah Kota Bengkulu

\section{SARAN}

1. Disarankan kepada perusahaan clear untuk meningkatkan iklannya terutama di media social seperti youtobe karena pada saat ini masyarakat lebih cenderung menggunaan media sosial untuk melakukan promosi

2. Disarankan kepada perusaaan clear untuk meningkatkan kualitas shampoo clear agar konsumen tetap mengingat shampoo clear pada saat ingin membeli shampoo.

\section{DAFTAR PUSTAKA}

Kotler Philip, 2013, Manajemen Pemasaran, edisi Millenium, terjemahan Hendra Teguh, dan Ronny A. Rusli, Penerbit : Prenhallindo, Jakarta

Kotler, Philip dan Kevin Lane Keller. 2009. "Manajemen Pemasaran”. Edisi 13 Jilid I dan II. Alih Bahasa; Bob Sabran, (2012), Erlangga, Jakarta. 
Machfoedz, Mahmud. 2010. Komunikasi Pemasaran Modern. Yogyakarta : Cakra Ilmu.

Peter, J. Paul dan Jerry C Olson. 2010. Perilaku Konsumen Dan Strategi Pemasarann. Terjemahan. Jakarta: Erlangga

Saladin, Djaslim, 2013, Prilaku Konsumen \& Pemasaran Strategi, Bandung; Linda Karya.

Schiffman, Leon.G. dan Kanuk, Leslie. 2010. Perilaku Konsumen. Jakarta: PT. Indeks

Simamora, Bilson,. 2011. Memenangkan Pasar dengan Pemasaran Efektif dan Profitabel. Jakarta: PT. Gramedia Pustaka Utama

Stanton. William J.. 2012. Prinsip Pemasaran. Cetakan Ketujuh. Jakarta : Penerbit Erlangga Sugiyono, 2013. Metode Penelitian Kuantitatif dan Kualitatiif dan R\&D. Bandung: Alfabeta

Sunarto. 2013. Perilaku Konsumen. Yogyakarta : AMUS Jogyakarta dan CV Ngeksigondo Utama.

Supranto. Limakrisna, Nandan, 2011, Perilaku Konsumen dan Strategi Pemasaran. Mitra Wacana Media: Jakarta

Sutisna. 2009. Perilaku Konsumen dan Komunikasi Pemasaran. Bandung. PT. Remaja Rosdakarya.

Swastha, Basu, dan Handoko, T. Hani, 2008, Manajemen Pemasaran, Analisa Perilaku Konsumen, edisi pertama, cetakan keempat, Penerbit : BPFE, Yogyakarta

Swastha. Basu. dan Irawan. 2010. Pengantar Bisnis Modern. Cetakan ketiga. Liberty. Yogyakarta

Tjiptono. Fandy . 2007. Manajemen Pelayanan Jasa. Penerbit Andi. Yogyakarta. 